\title{
Quality characteristics of natural yoghurts produced with lactulose supplementation
}

\author{
Jarosław Kliks ${ }^{*}$, Aleksandra Leśniak ${ }^{1}$, Marta Spruch², Sara Szołdra ${ }^{2}$ and Sławomir Czabaj ${ }^{3}$ \\ ${ }^{1}$ University of Zielona Góra, 9 Licealna Street, 65-417 Zielona Góra, Poland \\ ${ }^{2}$ Lubuski Centre for Innovation and Agricultural Implementation, Kalsk 122, 66-100, Sulechów, Poland \\ ${ }^{3}$ Opolski University of Technology, 76 Prószkowska Street, 45-758 Opole, Poland
}

\begin{abstract}
The fermentation of cow milk in natural yogurt production with 5 lactic acid bacteria (LAB) inoculum (Lactobacillus delbrueckii ssp. Bulgaricus, Lactobacillus acidophilus, Bifidobacterium lactis, Lactococcus lactis ssp. Cremoris, Lactococcus lactis ssp. Lactis) was performed to test the influence of lactulose addition on quality parameters. Highest concentration of lactic acid (LA) $\left(10.00 \mathrm{~g} \cdot \mathrm{L}^{-1}\right)$ and LA production rate after third hour of fermentation $\left(1.45 \mathrm{~g} \cdot \mathrm{L}^{-1} \cdot \mathrm{h}^{-1}\right)$ was noted in variant with $5 \%$ addition of dry matter of milk and 1\% lactulose (D.M.L.) samples. Highest concentration of LAB CFU per mL was reported in $1 \%$ lactulose supplemented samples (L.) during overall time of fermentation. Sensory evaluation of samples showed that use of $1 \%$ addition of lactulose and $5 \%$ addition of milk dry matter ensures good quality of final product. Achieving consumer acceptance proved in sensory evaluation performed by trained assessors.
\end{abstract}

\section{Introduction}

The name of yogurt comes from the Turkish word: " $y a-u r t$ ", which literally means "sour milk". Over 3000 years ago it was consumed by Babylonians, Egyptians and Hindus, to next come at the Turkish and Bulgarian tables. Previously it was prepared with sheep's, buffalo's, goat's and cow's milk. Nowadays yogurt is produced mainly from cow's milk. Even in 20th century yogurt was sold in Sweden pharmacies, because it was known to have a good effect on health [1].

Yogurt is a fermented milk product that has been prepared traditionally by spontaneous fermentation, simply allowing milk to sour at $40-45^{\circ} \mathrm{C}$. Modern yogurt production is a well-controlled process that utilizes ingredients such as: milk, milk powder, sugar, fruits, flavors, colorings, emulsifiers, stabilizers, and specific pure cultures of lactic acid bacteria (LAB) to conduct the fermentation process [2,3]. The characteristic taste and aroma of yogurt is caused by the fermentation of the individual components of milk like: lactose, glucose, and galactose. In yogurt the amount of lactic acid bacteria should be in the range $10^{6}$ $10^{7} \mathrm{CFU}$ per $1 \mathrm{~g}$ of product, and yeast $\geq 10^{2} \mathrm{CFU}$ per $1 \mathrm{~g}$ of the product $[4,5]$. The most common LAB are mesophilic and thermophilic strains such as: Lactococcus lactis, Lactobacillus casei, Lactobacillus plantarum, Leuconostoc, Lactobacillus delbrueckii and Streptococcus thermophiles with proven probiotic properties on human body [6,7].

Probiotics are live microorganisms, which influence good effect on the organism and maintenance of normal intestinal microflora. The consumption of fermented milk drinks helps to keep optimal level of normal intestinal microflora and have a scientifically proven therapeutic applications in: curing insomnia, soothing nerves, enhancement the immune system, reduction of serum cholesterol levels, anticarcinogenic activity (protection against colon and bladder cancer), alleviation of constipation, protection against traveller's diarrhea, prevention of infantile diarrhea, reduction of antibioticinduced diarrhea, prevention of hypercholesterolemia [8]. They have a good influence on bone and circulatory system, improves nutritional value of foods, protects from osteoporosis [9]. Fermented milk drinks reduce the risk of lactose-intolerance, because lactic acid bacteria by fermentation decompose lactose to glucose and galactose and produce the enzyme $\beta$-galactosidase, which hydrolyses lactose resulting in increased tolerance for dairy products [10]. Fermented milk drinks are good sources of vitamins and minerals $[3,11]$.

The most important process parameters of lactic acid fermentation of dairy products are lactic acid productivity and lactic acid content. High productivity rates helps to achieve a proper LA concentration in shorter time period which is vital for product stability and quality. Having great impact on organoleptic parameters such as: consistency, taste, aroma and general appearance.

\section{Materials and methods}

\section{Biological material and starter preparation}

1,5 g d.m. of lyophilized Lactobacillus delbrueckii ssp. Bulgaricus, Lactobacillus acidophilus, Bifidobacterium lactis, Lactococcus lactis ssp. Cremoris, Lactococcus lactis ssp. Lactis obtained from Gamma-Tech company (Poland), was rehydrated in $50 \mathrm{~mL}$ of sterile $(3,2 \%$ fat) cow milk for one hour. Then whole starer was transferred to $1 \mathrm{~L}$ of sterile (3,2\% fat) milk and incubated in $30^{\circ} \mathrm{C}$ for $24 \mathrm{~h}$.

\section{Yogurt preparation}

Four varieties of yogurt were prepared: a) with $5 \%$ addition of dry matter of milk and $1 \%$ lactulose (D.M.L), b) with $1 \%$ lactulose (L.), c)

${ }^{\star}$ Correspondence to: Kliks Jarosław, University of Zielona Góra, 9 Licealna Street, 65-417 Zielona Góra, Poland, E-mail: j.kliks@wzs.uz.zgora.pl

Key words: yogurt, fermentation, lactulose, quality

Received: February 20, 2019; Accepted: April 05, 2019; Published: April 08 2019 
5\% dry matter (D.M.) addition and d) control sample without addition of any component (clear 3.2\% fat cow milk) (CM). After normalization of pasteurized milk the inoculation with $100 \mathrm{~mL}$ starter $(2.1)$ per $1 \mathrm{~L}$ of milk was performed. All samples were prepared in triplicates and kept in temperature of $30^{\circ} \mathrm{C}$ with continuous stirring for 3 days.

\section{Determination of lactic acid bacteria}

MRS agar was used for the enumeration of Lactic acid bacteria's following Wang et al. [12] method. One milliliter of appropriate serial dilutions of each sample were pour-plated onto the appropriate media. After $48 \mathrm{~h}$ of incubation at $37^{\circ} \mathrm{C}$, the colonies that appeared on the plates were counted and the $\mathrm{CFU}$ per $\mathrm{mL}$ were calculated.

\section{Determination of lactic acid}

The fermentation courses were assessed according to the changes in concentration of lactic acid using high performance liquid chromatography (HPLC). Samples for chromatographic analyses were 10-fold diluted with de-ionized water and filtered through $0.2 \mu \mathrm{m}$ nylon membrane filter. Analyses were performed using Flexar HPLC chromatograph equipped with Rezex ROA-Organic Acid H+ column $(300 \times 7.8 \mathrm{~mm})$ (Phenomenex, Torrance, USA). The samples were loaded into $10 \mu \mathrm{L}$ injection loop and eluted at $20^{\circ} \mathrm{C}$ with $0.005 \mathrm{M} \mathrm{H}_{2} \mathrm{SO}_{4}$ as a mobile phase at a flow rate of $0.4 \mathrm{~mL} \cdot \mathrm{min}^{-1}$. The compounds were detected using refractive index detector, detection temperature was maintained at $20^{\circ} \mathrm{C}$.

\section{Sensory analysis}

Eight trained judges ( 4 men and 4 women aged from 25 to 40 ) performed sensory analysis.

The yogurts were kept and served at $12^{\circ} \mathrm{C}$, randomly and evaluated induplicate. During one session, maximum of 6 cups were assayed. Six sensory different attributes: general appearance, odor, consistency, color and taste were evaluated with five-point score scale.

\section{Statistical analysis}

Effects of lactic acid and $\mathrm{LAB}$ concentration during fermentation was measured by Tukey test at significance level of $\alpha=0.05$. In the twoway analysis of variance (ANOVA) was performed to detect significant differences in the analyte concentrations depending on the main factors studied (addition of dry substance of milk and lactulose). Packet Statistica in version 10 was used for data processing.

\section{Results and discussions}

Figure 1 presents relation of lactic acid (LA) concentration opposite to yogurt fermentation time. Basic LA concentration in milk oscillated around $1.8-3.0 \mathrm{~g} \cdot \mathrm{L}^{-1}$. Concentration of LA increases dynamically during first 6 hour of fermentation reach $8.4 \mathrm{~g} \cdot \mathrm{L}^{-1} \mathrm{LA}$ in D.M.L. yogurt which was highest concentration and only $6.7 \mathrm{~g} \cdot \mathrm{L}^{-1}$ in C.M. yogurt. Since 6 to 48 hour of fermentation concentrations of LA in all samples wasn't changed significantly. Analogical situation was observed by Brabandere and Baerdemaeker whom analyzed effects of process conditions on acidity of yogurts and notice the most dynamic reduction of $\mathrm{pH}$ (from 6.5 to 4.5 ) in first 6 hours of fermentation [13]. Other authors also reported analogical results in continues lactic acid fermentations of synthetic and natural media like $\mathrm{Fu}$ and Mathews [14] or Silva and Yang [15] which were study kinetics of lactose conversion to LA and notice $5-9 \mathrm{~g} \cdot \mathrm{L}^{-1}$ of LA after first 6 hour of process $[14,15]$.

Dynamics of fermentation showed in Figure 2. points that the first 3 hours of fermentation were the most turbulent in overall process. The

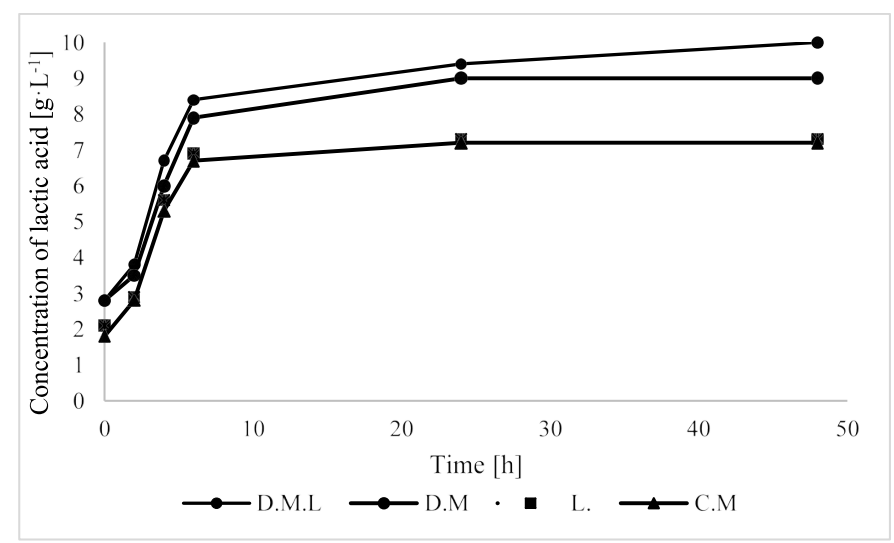

Figure 1. Lactic acid concentration changes during yogurt fermentation

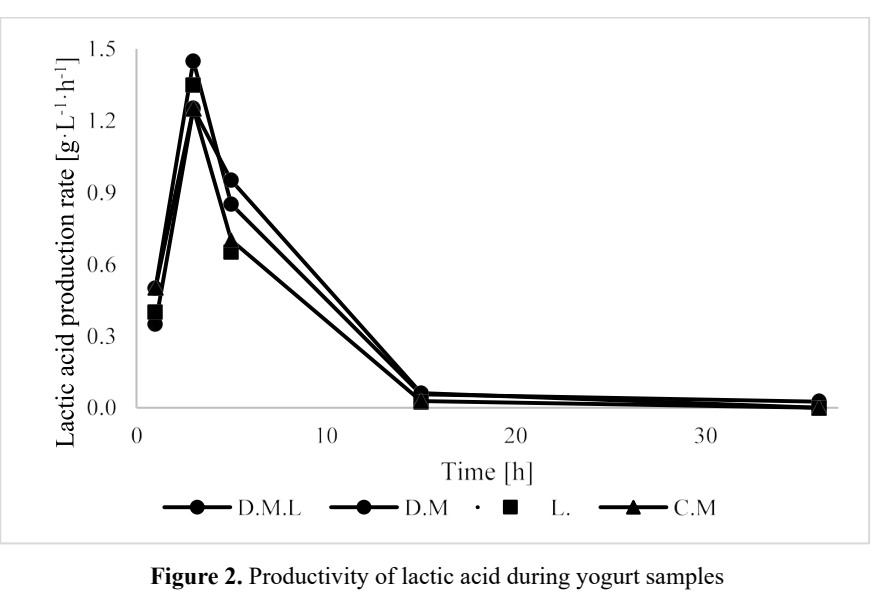

highest productivity was reported in D.M.L. yogurt variant reaching after 3rd hour of fermentation LA production rate of $1.45 \mathrm{~g} \cdot \mathrm{L}^{-1} \cdot \mathrm{h}^{-1}$. The lowest production rates were observed in C.M. and D.M. variants $(1.25$ $\left.\mathrm{g} \cdot \mathrm{L}^{-1} \cdot \mathrm{h}^{-1}\right)$. Wu et. al. proved that productivity of lactic acid in batch yogurt fermentation is highest in first hours after inoculation [16]. Also, other researchers who examined continues systems of lactic fermentation had been noted highest LA production rates in first 6 hours of fermentation [17-20].

LAB CFU concentration during fermentation process was showed on Figure 3. In 6 hours of fermentation the CFU of LAB increased to maximal concentration in all yogurts variants $(5,2-7,2$ $\mathrm{x} 10^{9} \mathrm{CFU}$ per $\mathrm{mL}$ ) except $\mathrm{L}$ yogurt variant samples which reached to $1,2 \times 10^{10} \mathrm{CFU}$ per $\mathrm{mL}$. Concentration of $\mathrm{LAB} \mathrm{CFU}$ per $\mathrm{mL}$ in yogurt after $6^{\text {th }}$ and hour has not changed until an experiment ends. Opposite results were noted by Wang et al. [12] who examined lactic mixed fermentation carried by Bifidobacterium infantis, Bifidobacterium longum with Lactobacillus acidophilus. Wang et al. [12] noted maximal log CFU of LAB after 24 hours of fermentation analogical to this study where $10^{8} \mathrm{CFU}$ per $\mathrm{mL}$ of $\mathrm{LAB}$ was found after second hour after inoculation [12]. Addition of lactulose and starter microbiological content could be an couse of highest results of CFU in this study. Gopal et al. [21] analyzed Bifidobacterium lactis and Lactobacillus rhamnosus noted $10^{6} \mathrm{CFU}$ per $\mathrm{mL}$ LAB as started concentration. In first 12 hours of process they noted for most of samples a dynamic growth of bacteria reaching to 8.5 $\mathrm{x} 10^{7} \mathrm{CFU}$ per $\mathrm{mL}$ [21]. Vinderola and others [22] proved that chemical composition of diary starter have great impact on bacterial growth during LAB fermentation [22]. Gustaw et al. [23] proved 
that addition of prebiotics like inulin, fructooligosaccharides and lactulose significantly effects on LAB growth in dairy products [23].

Sensory analysis was performed by 8 trained judges after 48 hours of yogurt fermentation. Every sample was obtained in $12^{\circ} \mathrm{C}$ and served after it was encoded. Average results of sensory analysis was showed on Figure 4. Scores for color and odour descriptors were similar in all samples $(4.6-5.0)$. The most significant differences between analyzed samples were observed in consistency. D.M.L. sample has been significantly high rated (5.0) in compare to other samples which had notes ranging from 2.0 to 4.2 points. General appearance and taste were similarly scored. The most high rated yogurt was D.M.L. variant in opposite to C.M. variant which has lowest rates of all sensory descriptors.

It was found that yogurt with addition of lactulose and dry substance (D.M.L) had better consistency in contrast to control sample (C.M) and yogurt with only lactulose (L) addition.

Guven et al. [24] proved that $1 \%$ of inulin addition with $4.3 \%$ addition dry substance had positive influence on consistence of yogurt, but too high addition of prebiotic had negative influence on consistence causing whey separation. Fat content had great influence on yogurt production. Addition of prebiotics allows to reduce the fat content [24].

Cruz et al. [25] proved also that increase of prebiotics addition have a negative influence on rheological properties of yogurt and rejection of the consumer. According to Cruz yogurt with addition $2.58 \%$ oligofructose was adequate and $25 \%$ was too high [25].

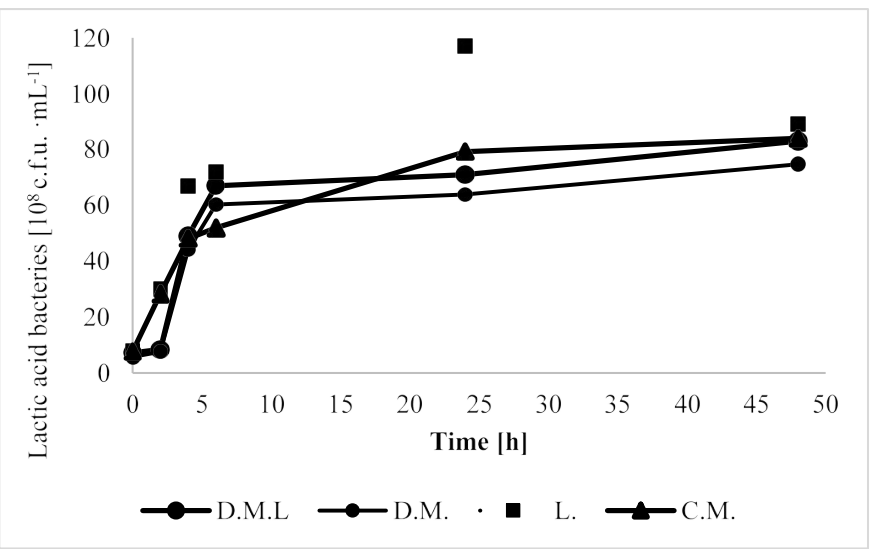

Figure 3. LAB concentration during yogurt fermentation

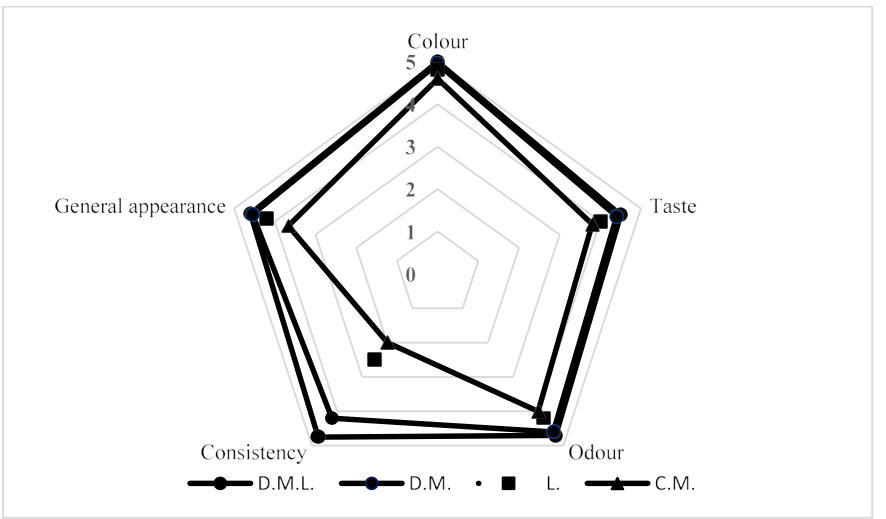

Figure 4. Sensory evaluation of analyzed yogurts
Allgeyer et al. [26] checked influence of addition polydextrose and chicory inulin on sensory propertiess of yogurt. They proved that addition of prebiotics and probiotics have positive influence on features organoleptic of yogurts. Moreover, bioyogurt arouse recognition of consumer [26].

In the study of Walsh et al. [27] yogurt with added inulin get the average rating. Types of prebiotics and other additions to milk can cause low note [27].

Ayrana et al. [28] improved that Chain length of prebiotics affected some characteristics of the yogurts. Inulin with a longer chain decreases syneresis and ensure better texture than sample control and inulin with a shorter chain but has worse taste [28].

\section{Conclusions}

Continues study of dairy products fermentation is an important subject in food chain quality and control improvement. Synergism of $1 \%$ addition lactulose mixed with milk dry matter has been most effective composition in this study of yogurt fermentation also effects highest's sensory evaluation results. Yogurt's sensory quality is an function of many factors which influences consumer acceptation consumers acceptation.

\section{References}

1. Prajapati JB, Nair BM (2008) Handbook of fermented functional foods, 3-7.

2. White CH, Kilara A, Hui YH (2008) Manufacturing yogurt and fermented milks. Ed. Chandan RC, John Wiley \& Sons.

3. Lourens-Hattingh A, Viljoen BC (2001) Yogurt as probiotic carrier food. Int Dairy J 11: $1-17$

4. FAO/WHO (1997) Codex Alimentarius Commision annex proposed draft standard for fermented milks (A11) CL 1997-MMP, November 1997.

5. FIL/IDF (1997) Commision D-legislation, standards of identity terminology fermented milk products, Doc. 316.

6. Cleveland J, Montville TJ, Nes IF, Chikindas ML (2001) Bacteriocins: Safe, natural antimicrobials for food preservation. Int J Food Microbiol 71:1-20.

7. Leroy F, De Vuyst L (2004) Lactic acid bacteria as functional starter cultures for the food fermentation industry. Trends Food Sci Technol 15: 67-78.

8. Perdigón G, de Moreno de LeBlanc A, Valdez J, Rachid M (2002) Role of yoghurt in the prevention of colon cancer. Eur J Clin Nutr 56 Suppl 3: S65-68. [Crossref]

9. Howlett J (2009) Functional foods - from science to health and claims. ILSI Europe.

10. Wilt TJ, Shaukat A, Shamliyan T, Taylor BC, MacDonald R, et al. (2010) Lactose intolerance and health. No. 192 (Prepared by the Minnesota Evidence-based Practice Center under contract no. HHSA 290-2007-10064-I.) AHRQ Publication No. 10-E004. Rockville, MD. Agency for healthcare research and quality.

11. Hertzler SR, Clancy SM (2003) Kefir improves lactose digestion and tolerance in adults with lactose maldigestion. J Am Diet Assoc 5: 582-587. [Crossref]

12. Wang Y, Yu RC, Chou CC (2002) Growth and survival of bifidobacteria and lactic acid bacteria during the fermentation and storage of cultured soymilk drinks. Food Microbiol 19: 501-508.

13. De Brabandere AG, De Baerdemaeker JG (1999) Effects of process conditions on the pH development during yogurt fermentation. J Food Eng 41: 221-227.

14. Fu W, Mathews AP (1999) Lactic acid production from lactose by Lactobacillus plantarum: Kinetic model and effects of $\mathrm{pH}$, substrate, and oxygen. Biochem Eng $J$ 3: $163-170$.

15. Silva EM, Yang ST (1995) Kinetics and stability of a fibrous-bed bioreactor for continuous production of lactic acid from unsupplemented acid whey. J Biotechnol 41: 59-70.

16. Wu H, Hulbert GJ, Mount JR (2000) Effects of ultrasound on milk homogenization and fermentation with yogurt starter. Innov Food Sci Emerg Technol 3: 211-218. 
17. Adamberg K, Kask S, Laht TM, Paalme T (2003) The effect of temperature and $\mathrm{pH}$ on the growth of lactic acid bacteria: a pH-auxostat study. Int J Food Microbiol 85: 171-183. [Crossref]

18. Doleyres Y, Fliss I, Lacroix C (2004) Increased stress tolerance of Bifidobacterium longum and Lactococcus lactis produced during continuous mixed-strain immobilizedcell fermentation. $J$ Appl Microbiol 97: 527-539. [Crossref]

19. Shene C, Bravo S (2007) Whey fermentation by Lactobacillus delbrueckii subsp. bulgaricus for exopolysaccharide production in continuous culture. Enzyme Microb Technol 40: 1578-1584.

20. Kaufman EN, Cooper SP, Davison BH (1994) Screening of resins for use in a biparticle fluidized-bed bioreactor for the continuous fermentation and separation of lactic acid. Appl Biochem Biotechnol 45: 545-554.

21. Gopal PK, Sullivan PA, Smart JB (2001) Utilisation of galacto-oligosaccharides as selective substrates for growth by lactic acid bacteria including Bifidobacterium lactis DR10 and Lactobacillus rhamnosus DR20. Int Dairy J11: 19-25.

22. Vinderola CG, Costa GA, Regenhardt S, Reinheimer JA (2002) Influence of compounds associated with fermented dairy products on the growth of lactic acid starter and probiotic bacteria. Int Dairy J 12: 579-589.
23. Gustaw W, Kordowska-Wiater M (2011) The influence of selected prebiotics on the growth of lactic acid bacteria for bio-yoghurt production. Acta Scientiarum Polonorum Technologia Alimentaria 10: 455-466.

24. Guven M, Yasar K, Karaca OB, Hayaloglu AA (2005) The effect of inulin as a fat replacer on the quality of set-type low-fat yogurt manufacture. Int J Dairy Technol 58: $180-184$.

25. Cruz AG, Cavalcanti RN, Guerreiro LMR, Sant'Ana AS, Nogueira LC, et al. (2013) Developing a prebiotic yogurt: Rheological, physico-chemical and microbiological aspects and adequacy of survival analysis methodology. J Food Eng 114: 323-330.

26. Allgeyer LC, Miller MJ, Lee SY (2010) Drivers of liking for yogurt drinks with prebiotics and probiotics. J Food Sci 75: S212-219. [Crossref]

27. Walsh H, Ross J, Hendricks G, Guo M (2010) Physico-chemical properties, probiotic survivability, microstructure, and acceptability of a yogurt-like symbiotic oats-based product using pre-polymerized whey protein as a gelation agent. J Food Sci 75: 327 337. [Crossref]

28. Aryana KJ, McGrew P (2007) Quality attributes of yogurt with Lactobacillus casei and various prebiotics. Lebenson Wiss Technol 40: 1808-1814.

Copyright: (2019 Kliks J. This is an open-access article distributed under the terms of the Creative Commons Attribution License, which permits unrestricted use, distribution, and reproduction in any medium, provided the original author and source are credited. 